\title{
Conversion of Aluminum Front Bumper System to Magnesium Material by Using Design of Experiment Method
}

\author{
Enes Kurtulus $^{1 *}$ and Gökhan Tekin ${ }^{2}$ \\ 0000-0003-4271-8566 ${ }^{1}, 0000-0002-1751-9891^{2}$ \\ ${ }^{1}$ Yesilova Holding R\&D Center, Bursa, 16335, Turkey
}

\section{Abstract}

Bumper and crash boxes are vehicle structural elements that convert the kinetic energy into deformation energy during an accident. In this study, the crash performance of a current aluminum crash bumper system is examined with a $40 \%$ offset $16 \mathrm{~km} / \mathrm{h}$ crash analysis. A magnesium crash bumper with improved crash performance is designed by this reference. In this design process, the Taguchi design of experiment method is used. Four different design variables and three-level combinations of these variables are used in Taguchi experiment design process as L9 level. The designs which corresponding to the variables are prepared, crash analyses are performed with explicit finite element analysis, and crash performances are examined. After obtaining the results, optimization is carried out with Minitab software; and the optimum design is achieved in crash performance and lightweight design.

Keywords: Crash bumper; DOE; Finite element analysis; Magnesium extrusion; Taguchi method
Research Article

http://doi.org/10.30939/ijastech..810401

$\begin{array}{ll}\text { Received } & 14.10 .2020 \\ \text { Revised } & 16.12 .2020 \\ \text { Accepted } & 23.12 .2020\end{array}$

* Corresponding author

Enes Kurtulus

enes.kurtulus@yesilova.com.tr

Address: Yesilova Holding, Istanbul Cd. No:648, Ovaakca Bursa, Turkey

Tel:+902244842330

\section{Introduction}

The National Highway Traffic Safety Administration (NHTSA) regulation, published in August 2016 in the United States, imposed emission limits on passenger vehicles on the road in 2017-2025. According to this regulation; In 2025, passenger cars' emission limitation will be pulled up to $163 \mathrm{~g} /$ mile. Besides, the fuel economy is targeted to be $54.5 \mathrm{mpg}$ in 2025 [1]. Automobile manufacturers will not only comply with this regulation but also compete with their competitors. Fuel economy approaches, of course, include the improvement of fuel quality, the development of highperformance engines and fuel injection systems, as well as a $10 \%$ reduction in vehicle weight, contributing to fuel economy in passenger cars by 6-8\% [2].

Magnesium is the lightest known structural metal and shows excellent workability. The most important known machinability characteristics are low cutting forces, good surface finish, and easy chip flow $[3,4]$. In automotive, chassis components, internal parts, and bodywork are the regions where magnesium alloys are preferred. Magnesium alloys are preferred due to their strength, ductility, fatigue strength, and impact resistance. Examples include seat frame, steering and steering column components, mirror housings, wheels, suspension arms, tailgate, instrument panel, brake, and clutch pedals. The second group of applications consists of the engine group and transmission components. Although there are existing applications of these parts, which require creep and corrosion resistance for high temperatures, their alloys continue to develop [5]. Today, magnesium is used in upper segment vehicles due to high raw material prices. It is thought that magnesium alloy can be preferred in middle segment passenger vehicles, with the expected decrease in the raw material price in the future. Magnesium investments of major automotive manufacturers such as Volkswagen, Toyota, and Ford in today's world prove the importance of using magnesium alloy in the automotive industry [6].

In the automotive industry, vehicle safety systems have been designed to protect occupants during an accident and can be considered in two classes: active safety systems and passive safety systems The active safety systems intervene before an accident occurs while the passive safety systems are designed to protect occupants during a crash. One of the passive safety systems are the energy absorbers in the vehicle chassis. The main purpose of using energy absorbers is to control the impact energy of a vehicle during impact and to prevent the transfer of high forces from bumper to main body. [7]

There are only several publications concerning energy absorption of thin-walled constructions made of magnesium alloys. Beggs et al. [8] crushed thin-walled profiles with circular crosssection made of magnesium alloy, steel and aluminum alloy. In works [9], [10] the energy absorption test results of two types of 
thin-walled, square cross-section magnesium profiles were presented: without rounded edges and with large radius. Gronostajski et al. [11] compared the energy absorption of the AZ31 magnesium alloy with two different steel materials on the example of the thinwalled model profiles made by the process of bending. Kaczyński et al. [12] demonstrated that the use of proper geometric shape allows to control the process of dynamic crushing and activate a new mechanism of energy absorption of thin-walled structures made of AZ31B magnesium alloy. Demirci and Yildiz [13] investigated the effect of different steel, aluminum and magnesium alloys materials and crash-box cross-sections on crash performance of thin-walled energy absorbers numerically.

\section{Material and Method}

\subsection{Investigation of Impact Performance of Existing Aluminum Crash Bumper System}

The dynamic crash analyses were simulated under the limit conditions specified for the front crash bumper assembly, which is currently used in mass production in a light commercial vehicle and produced from aluminum. The crash performance of the product was examined. In this examination, the absorbed energy and the maximum impact force are evaluated. These values will be the reference values for the final design for the magnesium crash bumper system.

The energy absorber geometries designed are imported into preprocess software and required definitions for finite element model such as mesh type, boundary conditions and loads are defined. The finite element model is analyzed by solver software and the results evaluated by post-process software. In this study, Altair Hypermesh, Radioss and Hyperview-Hypergraph are used as pre-processor, solver and post-processor, respectively $[14,15]$. Since crash analysis is investigated in very small-time intervals, time steps should be kept as low as possible for accurate and precise results. However, computational cost can increase significantly when the minimum element size is reduced, which brings some constraints in terms of computing time and processor requirements required for solutions. Accordingly, while creating the bumper system's finite element mesh, quad-dominated shell elements of an average of $4 \mathrm{x} 4 \mathrm{~mm}$ were used. It was ensured that the minimum element size did not fall below $2 \mathrm{~mm}$ due to the above-mentioned constraints.

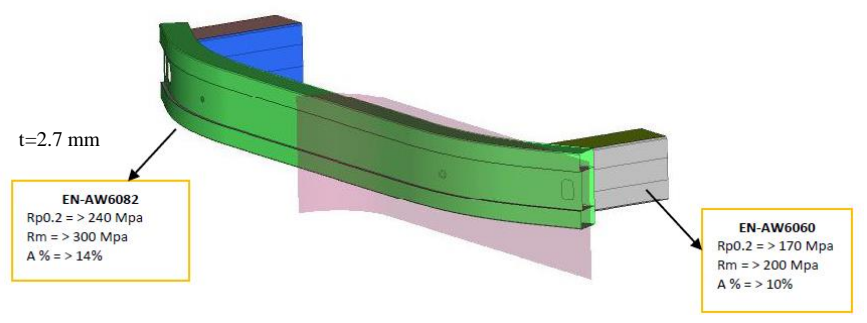

Fig. 1. Mesh model of the existing aluminum bumper system

In FE analysis, EN-AW6082 aluminum material was assigned for the bumper beam because of higher strength while EN-
AW6060 aluminum material was used for the crash box structures for better axial folding. Mechanical properties of the aluminum alloys and component thicknesses are given in Figure 1.

The bumper beam and crash-box components are modelled through isotropic elasto-plastic material using MAT36 material model. This law models isotropic elastoplastic material using userdefined functions for the work-hardening portion of the stressstrain curve (for example, plastic strain vs. stress) for different strain rates [14]. The selected aluminium materials are strain rate insensitive. Therefore, only one curve used to define material properties. The true stress-true strain diagrams created accordingly are given in Figure 2 for both materials.

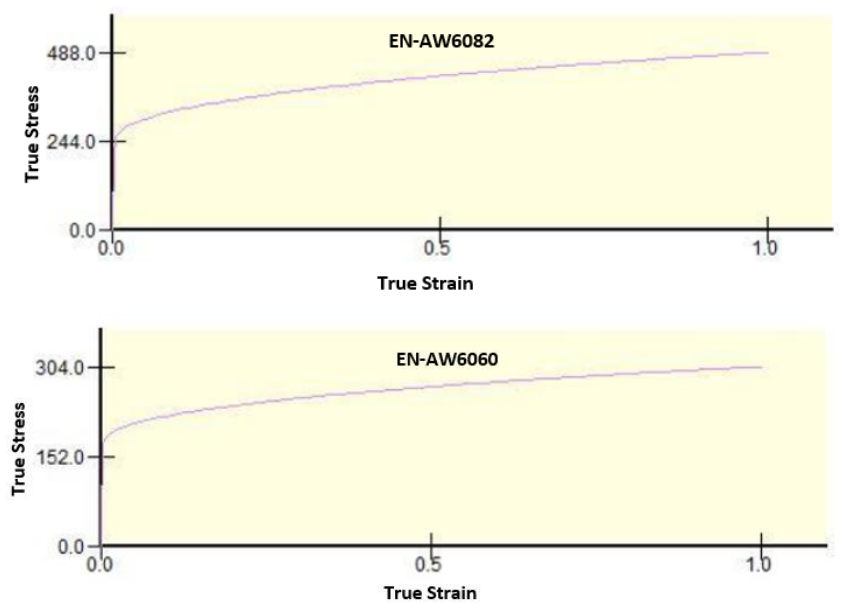

Fig. 2. True stress-strain graphics for EN-AW6082 and EN-AW6060 aluminum materials, respectively

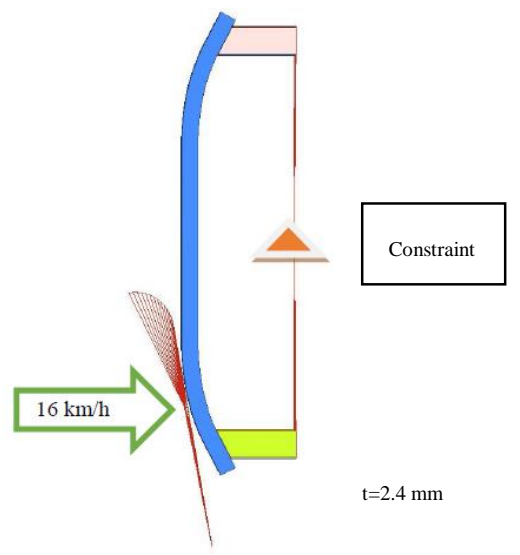

Fig. 3. Boundary conditions of the aluminum bumper system

The crash repair test is represented by an international working group [16] and has been standardized throughout the world for the front and rear. As such, these tests are also similarly used in other countries around the globe for the insurance classification. In a frontal crash, the vehicle hits a hard barrier at a speed of $16 \mathrm{~km} / \mathrm{h}$; the barrier covers $40 \%$ of the front of the vehicle and stands at an angle of 10 degrees. The bumper and the components behind it on one side have to dissipate the energy. According to this; the 
bumper system was constrained by limiting all degrees of freedom from the part where the crash boxes were connected to the chassis arms, and the rigid wall with a 10-degree angle moving at $16 \mathrm{~km} /$ $\mathrm{h}$ was crashed into $40 \%$ of the bumper.

The graph of the deformation behavior obtained from the analysis and the time-dependent changes of the maximum force and absorbed energy values are given in Figure 4.
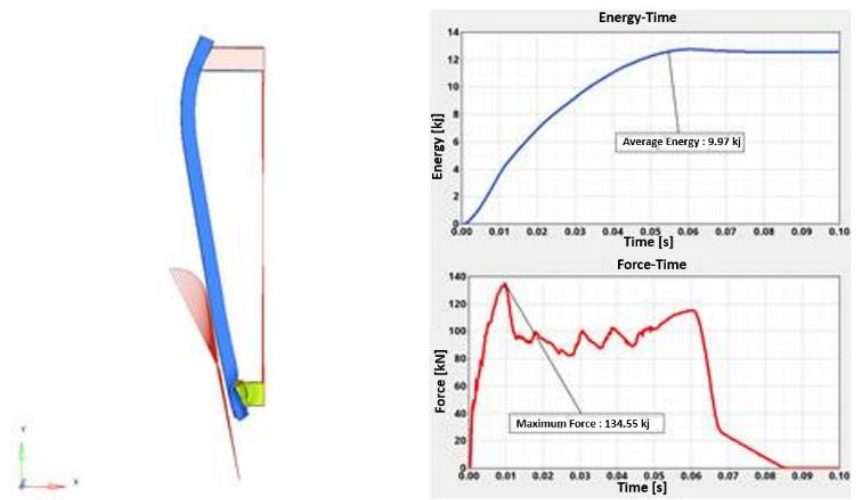

Fig. 4. Aluminum crash bumper deformation and force-time vs. energy-time graphs

\subsection{Magnesium Alloys and Magnesium Bumper Design}

It is known in the literature that AZ31, AZ61, AZ80 magnesium alloys have extrusion capabilities [17]. In this project, besides the mentioned alloys, different magnesium alloys such as AM30, AM50, and WE43 in the literature were examined. It was decided to continue working with AM50 and AZ31 alloys by examining their raw material costs, extrusion speeds, and manufacturability capabilities.

$70 \times 4 \mathrm{~mm}$ solid magnesium profiles were produced by the extrusion process from AM50 and AZ31 alloys. Tensile and compression tests were carried out with samples taken in the extrusion direction, perpendicular to the extrusion direction, and at an angle of 45 degrees to the extrusion direction. It has been observed that AM50 magnesium alloy has a higher isotropic behavior tendency than AZ31 alloy. In cases of high deformation occurring in a short time interval such as crash, energy absorption is achieved in a more controlled manner with an isotropic structure as much as possible.
It was decided to design the crash bumper parts with AM50 alloy. Hill tabulated elasto-plastic material model which is named as MAT43 has been selected to define both the tension and compression behavior of magnesium alloy. Stress - strain curves of AM50 magnesium alloy, defined in the material model, are shown in Figure 5 .

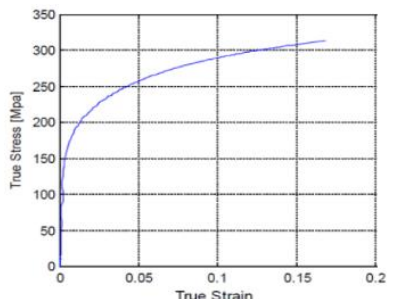

(a)

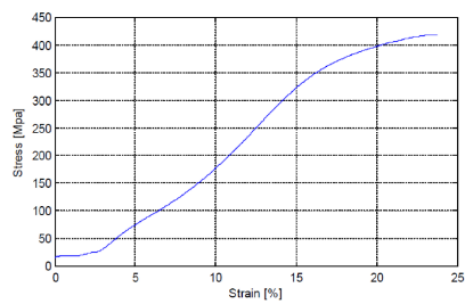

(b) (b)

Figure 5. Stress-strain graphics for (a) tension and (b) compression behavior of AM50 magnesium alloy

To compare the bumper system with the current aluminum model, the crushing behavior of the existing aluminum crash box was compared with the crash box designs that planned to be produced from magnesium alloy. Different cross-section designs have been implemented for the magnesium crash box as $3 \mathrm{~mm}$ thickness. While making these designs, the aluminum crash box dimensions used in the current model were considered not to cause any conflict in vehicle package dimensions. Besides, since the magnesium extrusion process requires more extrusion force than aluminum extrusion, no extra rib was used in sections. To determine the section geometry with the highest energy absorption, eight different (M1-M8) section geometries (square, round, rectangular, ellipse, hexagonal, slot, oval cut, unique form) and vertically grooved versions of these eight different section forms (M17- M24), a total of 16 different sections were designed, and their crushing behavior was investigated. Along with the section views and isometric views of all models, the designs crushing behaviors are given in the following figures (Figure 6-9). 

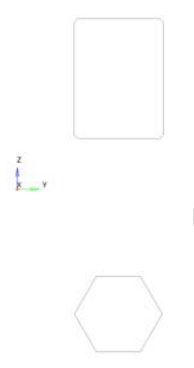

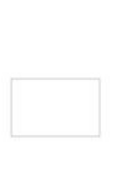

M7

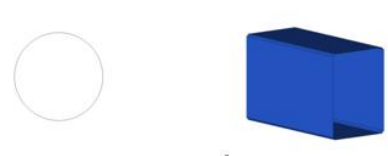

M1

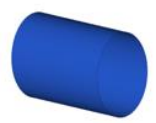

M5
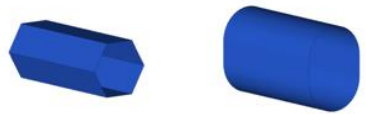

$M 2$

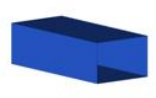

$L^{2}$

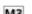

$m 4$

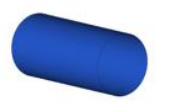

$t_{2}$

Figure 6. Cross-section and isometric views of models M1-M8

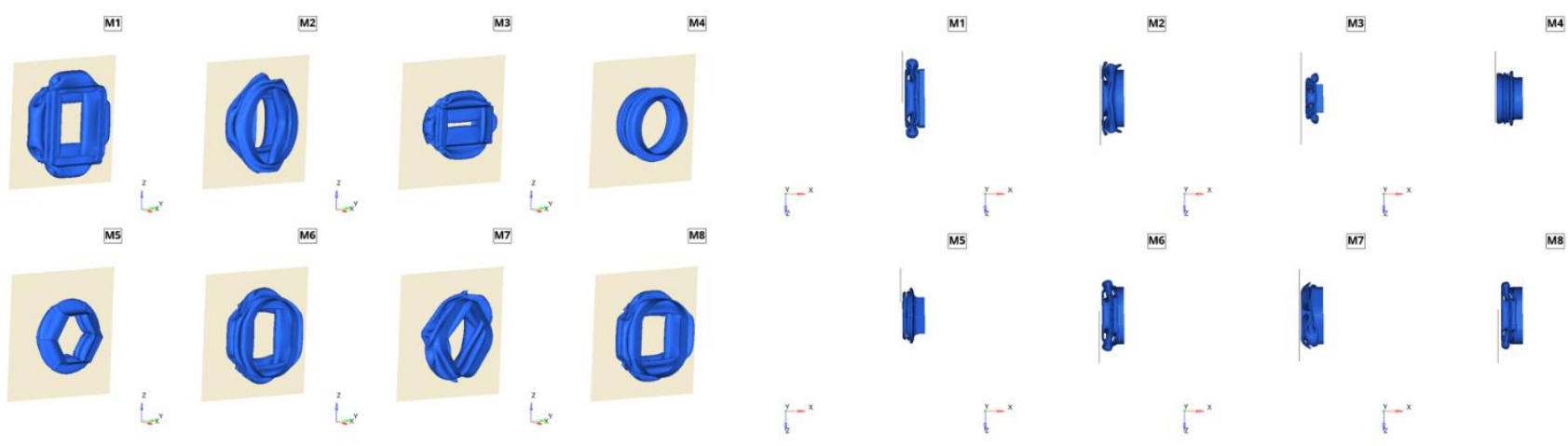

Figure 7. Crash behavior of models M1-M8 - isometric and side view

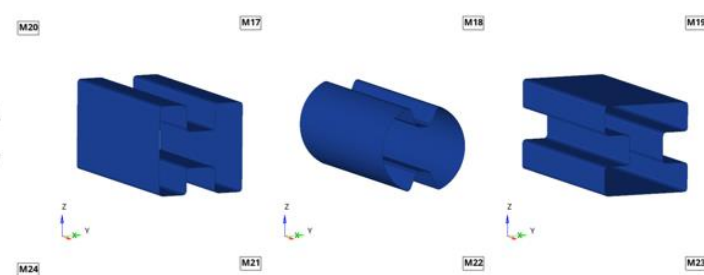

M19

$M 20$
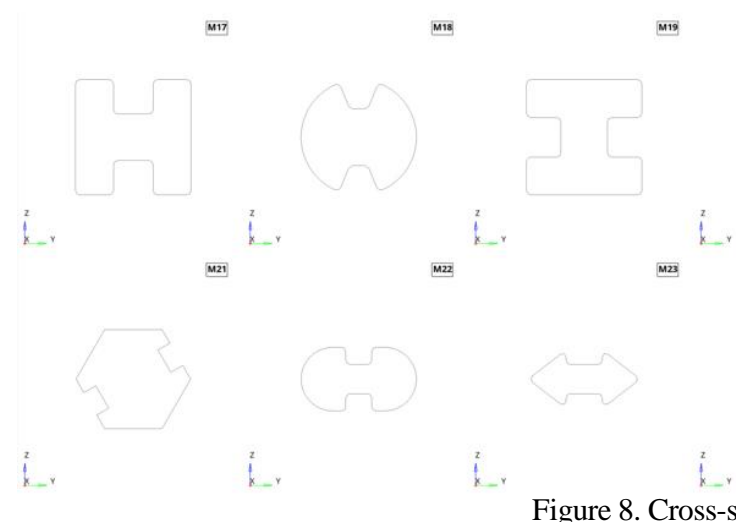

M24

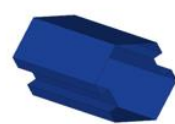

$i^{2} x^{2}$
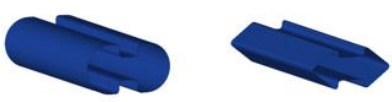

Figure 8. Cross-section and isometric views of models M17-M24
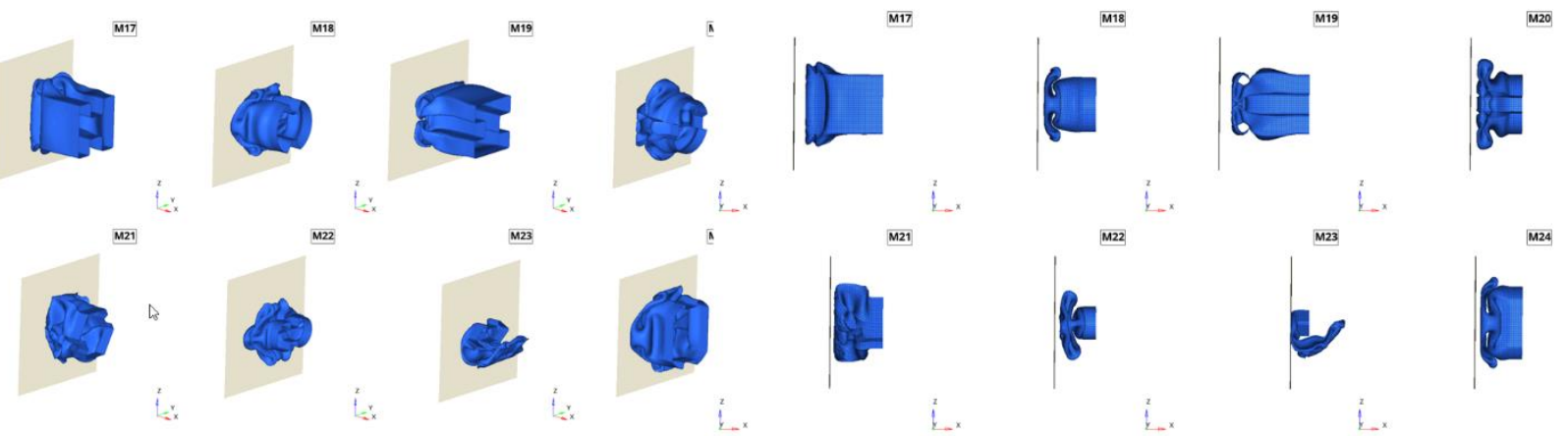

Figure 9. Crash behavior of models M17-M24 - isometric and side view 
Energy-time and force-time graphs related to the magnesium designs are given in comparison with the current aluminum crash box in Figure 10 and Figure 11, respectively. Crash performance data

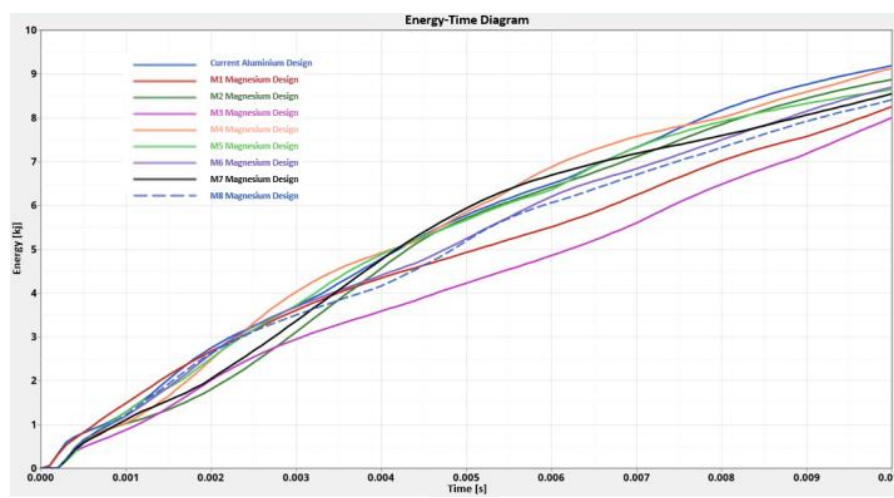

Figure 10. Energy-time graphs of magnesium crash box designs
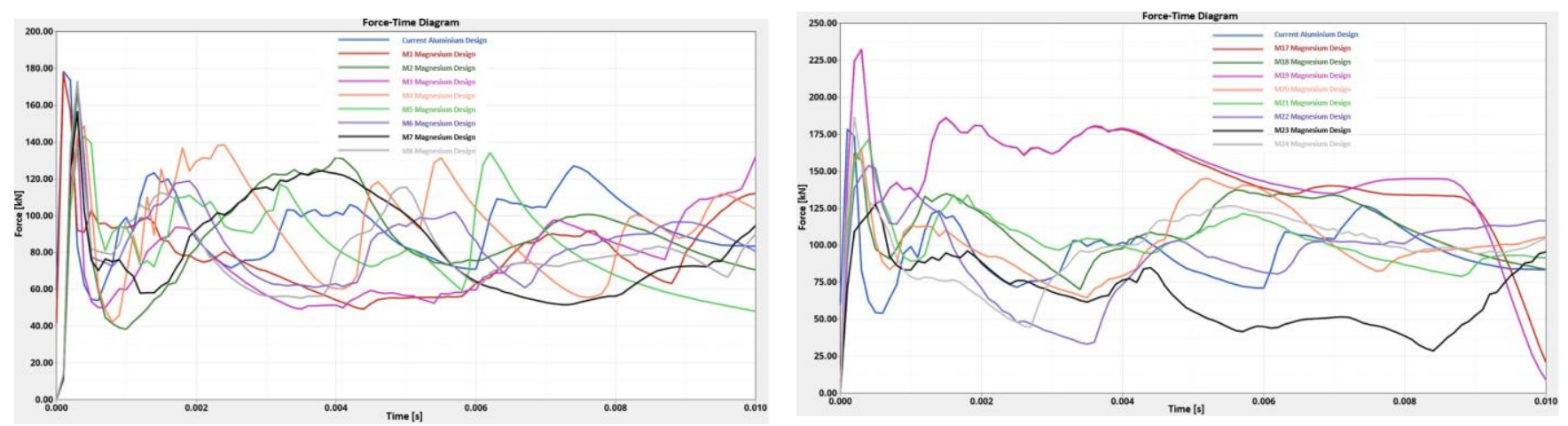

Figure 11. Force-time graphs of magnesium crash box designs.

Table 1. Crash performance data for magnesium crash box designs

\begin{tabular}{c|c|c|c|c|c|c}
\hline Model & $\begin{array}{r}\text { Absorbed } \\
\text { Energy [Kj] }\end{array}$ & $\begin{array}{c}\text { Max. } \\
\text { Crush Force } \\
{[\mathrm{kN}]}\end{array}$ & $\begin{array}{c}\text { Mean Crush } \\
\text { Force }[\mathrm{kN}]\end{array}$ & $\begin{array}{c}\text { Crushing } \\
\text { Force Efficiency } \\
{[\%]}\end{array}$ & $\begin{array}{c}\text { Specific Energy } \\
\text { Absorption } \\
{[\mathrm{kJ} / \mathrm{kg}]}\end{array}$ & $\begin{array}{c}\text { Weight } \\
{[\mathrm{gram}]}\end{array}$ \\
\hline Current Aluminum Design & 9.190 & 178.4 & 94.7 & 53.08 & 23.10 & 397.7 \\
\hline M1 Magnesium Design & 8.259 & 177.3 & 77.8 & 43.88 & 34.15 & 241.8 \\
\hline M2 Magnesium Design & 8.875 & 166.6 & 88.4 & 53.06 & 46.46 & 191 \\
\hline M3 Magnesium Design & 8.003 & 142.5 & 74.4 & 52.21 & 47.27 & 169.3 \\
\hline M4 Magnesium Design & 9.133 & 148.9 & 93.1 & 62.53 & 56.73 & 161 \\
\hline M5 Magnesium Design & 8.643 & 143.1 & 83.1 & 58.07 & 56.56 & 152.8 \\
\hline M6 Magnesium Design & 8.702 & 172.7 & 84.7 & 49.04 & 43.99 & 197.8 \\
\hline M7 Magnesium Design & 8.557 & 156.6 & 82.2 & 52.49 & 46.88 & 182.5 \\
\hline M8 Magnesium Design & 8.412 & 173.1 & 80 & 46.22 & 41.80 & 201.2 \\
\hline M17 Magnesium Design & 10.019 & 232.4 & 145.2 & 62.48 & 38.89 & 257.6 \\
\hline M18 Magnesium Design & 9.761 & 162.1 & 110 & 67.86 & 52.14 & 187.2 \\
\hline M19 Magnesium Design & 10.011 & 232.4 & 145.9 & 62.78 & 38.86 & 257.6 \\
\hline M20 Magnesium Design & 9.475 & 164.9 & 101.9 & 61.80 & 51.63 & 183.5 \\
\hline M21 Magnesium Design & 9.479 & 171.5 & 103.5 & 60.35 & 53.04 & 178.7 \\
\hline M22 Magnesium Design & 9.052 & 153.7 & 92.3 & 60.05 & 56.75 & 159.5 \\
\hline M23 Magnesium Design & 7.369 & 127.6 & 65.8 & 51.57 & 58.76 & 125.4 \\
\hline M24 Magnesium Design & 9.246 & 186.4 & 98.6 & 52.90 & 42.39 & 218.1 \\
\hline
\end{tabular}


As a result of the comparison, it has been observed that the circular cross-section design, called M4, is approximately \%10 superior in crushing force efficiency. It manifests better energy absorption than current aluminum model. This design is also $\% 60$ lighter than its current aluminum counterpart. The graphs of the M4 design crushing behaviors with the current aluminum crash box and the time-dependent graphs of energy and force values are given in Figure 12. The crash performance data of the M4 design model with the current aluminum crash box are given in Table 2 .
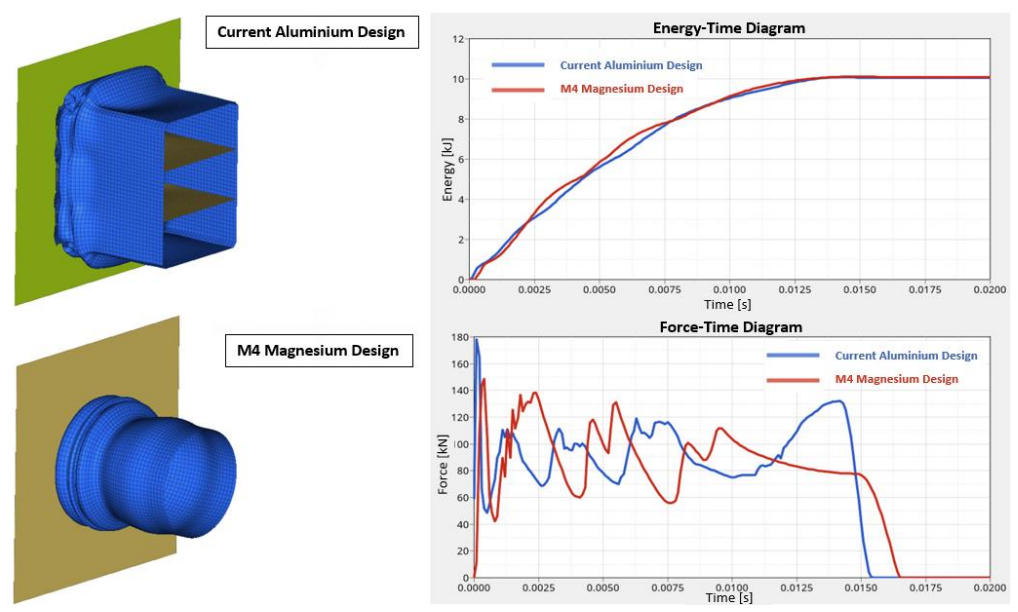

Figure 12. The crash performance of the existing aluminum crash box and the magnesium design crash box named M4

Table 2. M4 magnesium design crash box comparison with current aluminum crash box

\begin{tabular}{c|c|c|c|c|c|c}
\hline Model & $\begin{array}{r}\text { Absorbed } \\
\text { Energy [Kj] }\end{array}$ & $\begin{array}{c}\text { Max. Crush } \\
\text { Force }[\mathrm{kN}]\end{array}$ & $\begin{array}{c}\text { Mean Crush } \\
\text { Force }[\mathrm{kN}]\end{array}$ & $\begin{array}{c}\text { Crushing Force } \\
\text { Efficiency [\%] }\end{array}$ & $\begin{array}{c}\text { Specific Energy } \\
\text { Absorption [kJ/kg] }\end{array}$ & $\begin{array}{c}\text { Weight } \\
{[\mathrm{gram}]}\end{array}$ \\
\hline Current Aluminum Design & 9.190 & 178.4 & 94.7 & 53.08 & 23.10 & 397.7 \\
\hline M4 Magnesium Design & 9.133 & 148.9 & 93.1 & 62.53 & 56.72 & 161 \\
\hline
\end{tabular}

\subsection{Design of Experiment and Optimization Study}

There are different methods used for crashworthiness optimization of thin-walled structures in the literature [18]. In this study, the Taguchi design of experiment method was used for the magnesium alloy bumper assembly design. According to this, in the design of experiment, a design model was created in 3 levels with four different variables (factors). Design parameters were determined as the number of bumper beam ribs, bumper beam wall thickness, bumper beam middle width, and crash box wall thickness. While determining the lower and upper limits for these parameters; cost, manufacturability, weight reduction target, etc. evaluated within the scope. Since the design is also planned to be used in the current vehicle, package size of the aluminum bumper system has been considered. Design variables and the values of these variables are given in Table 3.

Table 3. Design variables and their values

\begin{tabular}{c|c|c|c}
\hline $\begin{array}{c}\text { Bumper Beam } \\
\text { Ribs }\end{array}$ & $\begin{array}{c}\text { Bumper Beam Wall Thickness } \\
{[\mathrm{mm}]}\end{array}$ & $\begin{array}{c}\text { Crash Box Wall Thickness } \\
{[\mathrm{mm}]}\end{array}$ & $\begin{array}{c}\text { Bumper Beam Middle Width } \\
{[\mathrm{mm}]}\end{array}$ \\
\hline 0 & 3 & 2.5 & 31 \\
\hline 1 & 3.5 & 3 & 34 \\
\hline 2 & 4 & 3.5 & 36 \\
\hline
\end{tabular}
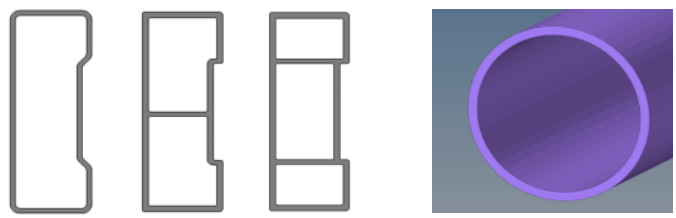

Figure 13. Design variables 
Taguchi experiment design table for four factors and three levels is prepared according to the L9 level [19]. The design combinations obtained with the Taguchi method are given in Table 4. Energy-time and force-time graphs for nine different designs are given in Figure 14 compared to the existing aluminum bumper assembly. Crash performance data for all designs are given in Table 5 in comparison with the existing aluminum bumper assembly.

Table 4. L9 Taguchi table

\begin{tabular}{c|c|c|c|c}
\hline $\begin{array}{c}\text { Design } \\
\text { No }\end{array}$ & $\begin{array}{c}\text { Bumper Beam } \\
\text { Ribs }\end{array}$ & $\begin{array}{c}\text { Bumper Beam Wall } \\
\text { Thickness [mm] }\end{array}$ & $\begin{array}{c}\text { Crash Box Wall } \\
\text { Thickness [mm] }\end{array}$ & $\begin{array}{c}\text { Bumper Beam Middle } \\
\text { Width [mm] }\end{array}$ \\
\hline 1 & 0 & 3 & 2.5 & 31 \\
\hline 2 & 0 & 3.5 & 3 & 34 \\
\hline 3 & 0 & 4 & 3 & 36 \\
\hline 4 & 1 & 3 & 3.5 & 36 \\
\hline 5 & 1 & 3.5 & 2.5 & 34 \\
\hline 6 & 1 & 4 & 3.5 & 36 \\
\hline 7 & 2 & 3 & 2.5 & 31 \\
\hline 8 & 2 & 3.5 & 3 & \\
\hline 9
\end{tabular}
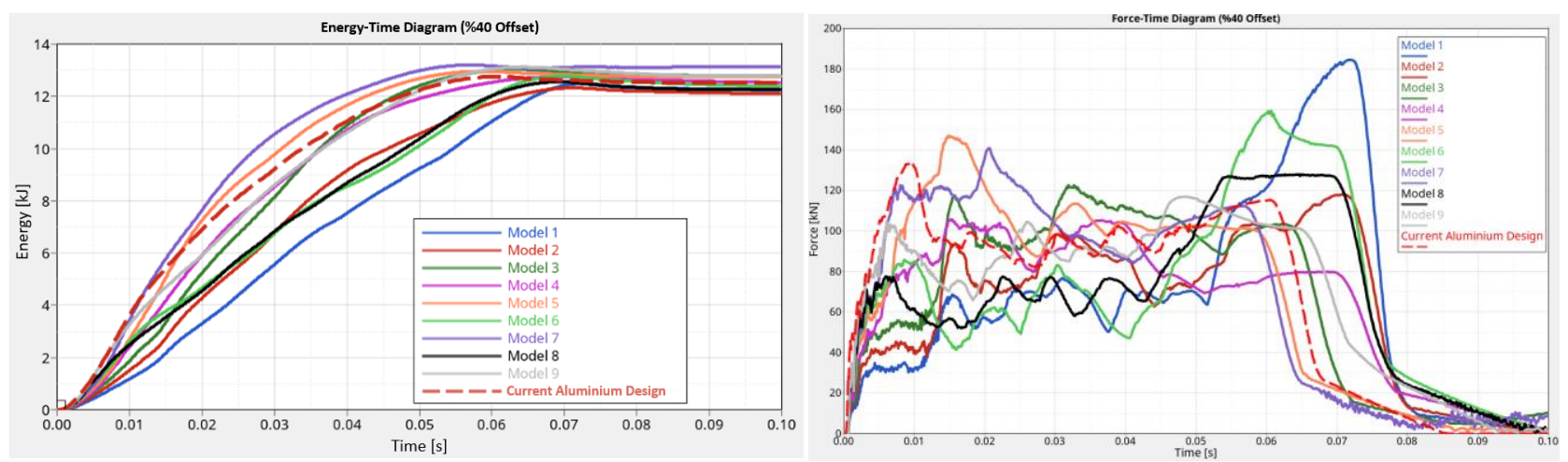

Figure 14. Energy-time and force-time graphs obtained from crash analysis

Table 5. Crash performances and model weights according to the analysis

\begin{tabular}{|c|c|c|c|c|c|c|c|c|c|}
\hline $\begin{array}{l}\text { Design } \\
\text { No }\end{array}$ & $\begin{array}{c}\text { Bumper } \\
\text { Beam Ribs }\end{array}$ & $\begin{array}{c}\text { Bumper } \\
\text { Beam } \\
\text { Wall } \\
\text { Thickness } \\
{[\mathrm{mm}]}\end{array}$ & $\begin{array}{c}\text { Crash } \\
\text { Box Wall } \\
\text { Thickness } \\
{[\mathrm{mm}]}\end{array}$ & $\begin{array}{l}\text { Bumper } \\
\text { Beam } \\
\text { Middle } \\
\text { Width } \\
{[\mathrm{mm}]} \\
\end{array}$ & $\begin{array}{l}\text { Displacement } \\
{[\mathrm{mm}]}\end{array}$ & $\begin{array}{c}\text { Max. } \\
\text { Crush } \\
\text { Force }[k N]\end{array}$ & $\begin{array}{r}\text { Absorbed } \\
\text { Energy [Kj] }\end{array}$ & $\begin{array}{c}\text { Specific } \\
\text { Energy } \\
\text { Absorp- } \\
\text { tion } \\
{[\mathrm{kJ} / \mathrm{kg}]} \\
\end{array}$ & $\begin{array}{l}\text { Weight } \\
{[\mathrm{g}]}\end{array}$ \\
\hline 1 & 0 & 3 & 2.5 & 31 & 205.3 & 184.57 & 8.09 & 3.98 & 2031 \\
\hline 2 & 0 & 3.5 & 3 & 34 & 180.7 & 118.1 & 8.66 & 3.69 & 2344 \\
\hline 3 & 0 & 4 & 3.5 & 36 & 157.1 & 122.57 & 9.64 & 3.60 & 2675 \\
\hline 4 & 1 & 3 & 3 & 36 & 157.3 & 105.6 & 9.61 & 4.22 & 2274 \\
\hline 5 & 1 & 3.5 & 3.5 & 31 & 133.7 & 147.03 & 10.10 & 3.76 & 2686 \\
\hline 6 & 1 & 4 & 2.5 & 34 & 185.4 & 159.35 & 8.85 & 3.08 & 2866 \\
\hline 7 & 2 & 3 & 3.5 & 34 & 129.2 & 140.7 & 10.50 & 4.13 & 2541 \\
\hline 8 & 2 & 3.5 & 2.5 & 36 & 180.1 & 127.87 & 8.82 & 3.18 & 2775 \\
\hline 9 & 2 & 4 & 3 & 31 & 154.9 & 117.01 & 9.87 & 3.10 & 3186 \\
\hline $\begin{array}{c}\text { Current } \\
\text { Aluminum } \\
\text { Design }\end{array}$ & 2 & 2.7 & 2.2 & 34 & 140 & 134.55 & 9.97 & 2.66 & 3741 \\
\hline
\end{tabular}


In line with these data, optimization was carried out with the help of Minitab software. While performing the optimization study, the displacement in the current model was defined as the optimization constraint. It was tried to reach the optimum solution with the lowest maximum force and the highest energy absorption. Crash analyses were also performed with Radioss on the design variables with the necessary adjustments, considering the manufacturability constraints. In Table 6, Minitab optimization results which are obtained from the design of experiment study, and Radioss crash analysis outputs are given together. It was also compared with the existing aluminum model. The graph of the deformation behavior obtained from the analysis of the optimum model and the time-dependent changes of the maximum force and energy are given in Figure 15 compared to the existing aluminum model.

Table 6. Comparison of Minitab and Radioss solutions

\begin{tabular}{|c|c|c|c|c|c|c|c|c|c|}
\hline & $\begin{array}{l}\text { Bumper } \\
\text { Beam } \\
\text { Ribs }\end{array}$ & $\begin{array}{c}\text { Bumper } \\
\text { Beam } \\
\text { Wall } \\
\text { Thickness } \\
{[\mathrm{mm}]}\end{array}$ & $\begin{array}{c}\text { Crash } \\
\text { Box Wall } \\
\text { Thickness } \\
{[\mathrm{mm}]}\end{array}$ & $\begin{array}{l}\text { Bumper } \\
\text { Beam } \\
\text { Middle } \\
\text { Width } \\
{[\mathrm{mm}]}\end{array}$ & $\begin{array}{l}\text { Displacement } \\
\text { [mm] }\end{array}$ & $\begin{array}{l}\text { Max. } \\
\text { Crush } \\
\text { Force } \\
{[\mathrm{kN}]}\end{array}$ & $\begin{array}{r}\text { Absorbed } \\
\text { Energy }[\mathrm{Kj}]\end{array}$ & $\begin{array}{c}\text { Specific } \\
\text { Energy Ab- } \\
\text { sorption } \\
{[\mathrm{kJ} / \mathrm{kg}]}\end{array}$ & $\begin{array}{l}\text { Weight } \\
{[\mathrm{g}]}\end{array}$ \\
\hline $\begin{array}{l}\text { Minitab } \\
\text { Optimum } \\
\text { Results }\end{array}$ & 1.98 & 3.97 & 3.26 & 35.95 & 140.00 & 106 & 10.27 & - & - \\
\hline $\begin{array}{c}\text { Radioss } \\
\text { Optimum } \\
\text { Results } \\
\end{array}$ & 2 & 4 & 3.25 & 36 & 140.10 & 124.1 & 10.34 & 3.21 & 3218 \\
\hline $\begin{array}{c}\text { Current } \\
\text { Aluminum } \\
\text { Design } \\
\end{array}$ & 2 & 2.7 & 2.2 & 34 & 140.00 & 134.55 & 9.97 & 2.66 & 3741 \\
\hline
\end{tabular}
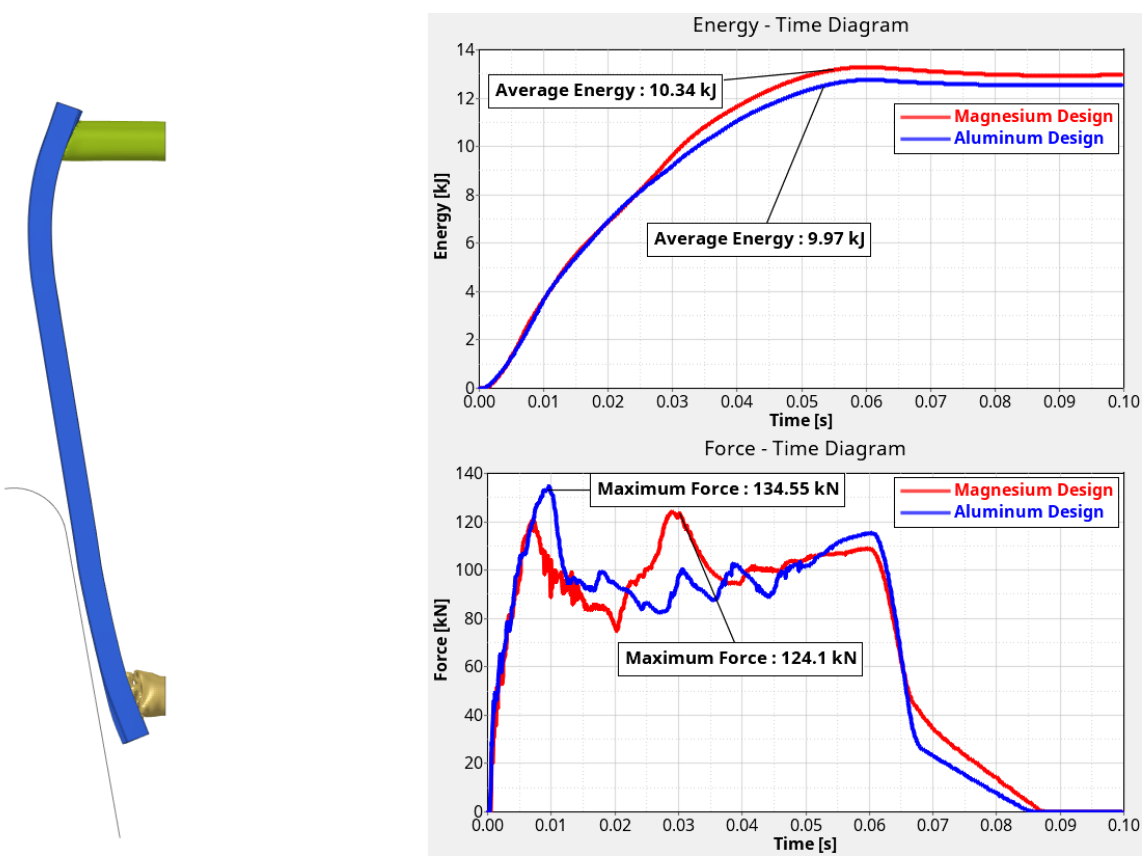

Figure 15. Comparison of current model and optimum model crash performance. 


\section{Conclusions}

In this study, an aluminum crash bumper assembly which is used in serial production in a light commercial vehicle, was transformed into a magnesium alloy design with the help of the design of experiment method. Firstly, the study was carried out for the optimum cross-section of the crash box. The most suitable design was determined by comparing the different designs revealed with the current aluminum crash box model in terms of crash performance. During the next design work, 3 different levels were determined for four different design parameters as; the number of bumper beam ribs, bumper beam wall thickness, bumper beam middle width, and crash box wall thickness. Different design variations were created according to the Taguchi table and the crash performances of these designs were obtained with dynamic finite element crash simulations. According to the last optimization study, the crash performance has been improved by approximately $20 \%$, and weight of the design was reduced by $15 \%$ compared to the aluminum alloy solution. In the next step of the study, the designed crash bumper assembly will be produced by the magnesium extrusion method. It will be physically tested, and the test results will be compared with simulation results.

\section{Acknowledgment}

This study was supported by TUBITAK/TURKEY in frame of the project code of 1511-1160380. As researchers, we thank the TUBITAK/TURKEY.

\section{Conflict of Interest Statement}

The authors declare that there is no conflict of interest.

\section{CRediT Author Statement}

Enes Kurtulus: Conceptualization, Writing-original draft, Validation, Formal analysis, Gökhan Tekin: Conceptualization, Supervision.

\section{References}

[1] Office of Transportation and Air Quality, Regulatory Announcement:EPA and NHTSA Propose to Extend the National Program to Reduce Greenhouse Gases and Improve Fuel Economy for Cars and Trucks. 2011; EPA-420-F-11-038.

[2] Kiani M, Gandikota I, Rohani R, Motoyama K. Design of lightweight magnesium car body structure under crash \& vibration constraints. J. Magnes. Alloy. 2014; 2:99-108.

[3] Musfirah AH, Jaharah AG. Magnesium and aluminium alloys in automotive industry. J. Appl. Sci. Res. 2012;8(9):4865-4875.

[4] Mert F. Magnezyum Alaşımlarının İşlenmesi. 3. Ulusal Talaşlı İmalat Sempozyumu. 04-05 Ekim 2012, Ankara, Türkiye.

[5] Akdoğan A. Magnezyum ve Magnezyum Alaşımları Ders Notları. 2008, YTU.

[6] Webb D. Magnesium Supply and Demand 2004. The 62nd Annual World Magnesium Conference. 22-24 May 2005, Berlin, Germany.

[7] Alghamdi AAA. Collapsible impact energy absorbers: an overview.
Thin-Walled Struct. 2001;39(2):189-213.

[8] Beggs PD, Song W, Easton M. Failure modes during uniaxial deformation of magnesium alloy AZ31B tubes. Int J Mech Sci. 2010;52:1634-1645.

[9] Steglich D, Tian X, Bohlen J, Riekehr S, Kashaev N, Bargmann S, et al. Crashworthiness of magnesium sheet structures. Mater Sci Forum. 2013; 765: 590-594.

[10] Steglich D, Bohlen J, Tian X, Riekehr S, Kashaev N, Kainer KU, Huber N. Experimental and numerical crushing analyses of thinwalled magnesium profiles. Int J Crashworthiness. 2015; 20(2):177-190.

[11] Gronostajski Z, Kaczyński P, Polak S, Bartczak B. Energy absorption of thin-walled profiles made of AZ31 magnesium alloy. ThinWalled Struct. 2018; 122:491-500.

[12] Kaczyński P, Gronostajski Z, Polak S. Progressive crushing as a new mechanism of energy absorption. The crushing study of magnesium alloy crash-boxes. Int. J. Impact Eng. 2019; 124:1-8.

[13] Demirci E, Yildiz AR. An investigation of the crash performance of magnesium, aluminum and advanced high strength steels and different cross-sections for vehicle thin-walled energy absorbers. Mater. Test. 2018; 60(7-8):661-668.

[14] Altair Hyperworks, Radioss User Guide, 2019

[15] S-t Engineering, http://www.s-t.com.tr/implicit_explicit_sonlu_ elemanlar_cozucu.html, 5.08.2020.

[16] AZT Test Procedure, https://www.rcar.org/Papers/Procedures/CrashStandards_GermanRatingSystem.pdf. 05.08.2020

[17] Öztürk F, Kaçar İ. Magnezyum Alaşımları ve Kullanım Alanlarının İncelenmesi. Niğde Üniversitesi Mühendislik Bilimleri Dergisi. 2012; 1:12-20.

[18] Albak Eİ. Multi-objective crashworthiness optimization of thinwalled multi-cell tubes with different wall lengths. Int J Crashworthiness. 2020;1-18.

[19] Gökçe B, Taşgetiren S. Kalite İçin Deney Tasarımı. Makine Teknolojileri Elektronik Dergisi. 2009; 6(1):71-83. 